\title{
Examining the organizational citizenship behavior as the outcome of organizational commitment: Case study of universities in Ilam
}

\author{
Meysam Mirabizadeh ${ }^{*}$ and Sajad Gheitasi
}

Department Industrial Engineering, Islamic Azad University, Ilam Branch, Iran

\begin{tabular}{l}
\hline A R T I C L E I N F O \\
\hline Article history: \\
Received July 10, 2011 \\
Received in Revised form \\
October, 3, 2011 \\
Accepted 10 January 2012 \\
Available online \\
16 January 2012 \\
\hline Keywords: \\
Organizational citizenship \\
behavior \\
Organizational Commitment \\
LISREL
\end{tabular}

\begin{abstract}
A B S T R A C T
Organizational Citizenship Behavior (OCB) is one of the most important factors on improving the efficiency of organizations. The proposed study of this paper investigates the relative importance of OCB in different universities located in the province of Ilam, Iran. The study distributes 220 questionnaires, collects 199 and analyzes them using LISREL software package. There are four hypotheses associated with this survey and the results indicate that educational opportunities, work-life policy, empowerment activities have strong positive relationship on organizational commitment and organizational commitment also influences organizational citizenship behavior, accordingly.
\end{abstract}

\section{Introduction}

For over 65 years, there have been tremendous efforts on investigating employees' behavior s, which are exclusive characteristics of any one (Koster et al., 2006; Noor, 2009). Organizational citizenship behavior (OCB) is people's right, which is not determined by organizational award and it is not part of employees' responsibilities (Podsakoff et al., 1990). OCB has three aspects: first, the activity is volunteer job, second, it is associated with organization and it has multi dimensional aspects (Bienstock et al., 2003). According to Podsakoff et al. (1990, 2000), there were only 13 articles associated with OCB between years of 1988 and 1993. However, there was a growing interest from year 1993 to 1998, which yields over 122 articles in different fields of human resource management, marketing, health care, psychology, strategic management, etc.

These studies are concentrated in four aspects including job and leadership specification, personal characteristics and leadership behavior. Today, there is an intensive competition among organizations, which is the results of a steady increase on knowledge (Gautam et al., 2004; Šušnjar \& Zimanji, 2006). Organ (1995) reported fairness and organizational commitment as two most

* Corresponding author. Tel: +989188425250

E-mail addresses: meysammirabizadeh@yahoo.com (M. Mirabizadeh) 
important influencing factors on organizational behavior based on a comprehensive study on 55 different studies. Meyer and Allen (1984) believed there were three organizational commitment including moral continuous and ethical commitments. These have strong relationship between OCB and commitment. According to Porter et al. (1974) commitment involves with employees' moral and emotional commitment where employees specify their identity based on an organizational objectives. Organizational commitment specifies anyone's efforts and willingness on reaching firm's objectives (Robbins, 1993). Joolideh et al. (2009) explained that a good educational program is designed based on the professional university professors who are responsible for leading the business unit. Chughtai (2006) explained that an existence commitment among university professors help organization increase their efficiencies.

\section{Literature review}

\subsection{Training and development opportunities}

Training opportunities could always create better chances for increasing employees' abilities to improve capabilities of organizations, which yields to profit maximization (Susnjar, 2006). During the past ten years, there have been tremendous changes on educational systems in the world (Garavan et al., 1993). There are many evidences to believe that in this century, human resources play key role on the success of organizations. Creative human resources along with good background educational and background skills build organizations' future (Khayyat, 1998).

Education improves relationship between employee and management (Kalleberg, 1994) and many organizations invest on education to reach their objectives (Liu, 2007). Nevertheless, continuous improvement and learning is ignored among many individuals (Brown et al., 2002). Chang (1999) reported that when an organization invests on education, the management is worried about employees' commitment and learning is a method to increase their commitments (Dockel et al., 2006). The first hypothesis of this paper is as follows,

H1: Training and development opportunities have positive relationship with organizational commitment.

\subsection{Work-life policy}

There have been many studies on measuring the impact of various factors on working environment such as employees' responsibilities, conflict of interests, family responsibilities, etc. (Glass, 1998; Kahn et al., 1964). According to Pleck et al. (1980), too much work, afternoon shift work, working conditions with no flexibility, the lack of ability to leave the job in emergency conditions are among the most important challenges in work-life issues. Khan et al. (1964) believed work pressure plays an essential role on creating conflict on work-life policy. In fact, when such conflict happens people with different personalities may have serious problems (Katz et al.,1978; Schwartz, 1996; Pleck et al., 1980).

According to Simon et al. (2006) there are three types of conflicts: the first one happens when there is a conflict for the time spent in job and other family oriented issues. The second one is associated with pressure, which occurs once the performance of a person is reduced as a result of stressful reaction of the third party.

The third one is the conflict on behavior, which is the result of change on position. Schwarts (1996) work-life could improve people's lives and could increase their interest in their work. Deery (2008) reported that different strategies for creating a balance between work and life created by employees impact their performance, significantly because if there is a conflict between these two issues, we may see a clear problem in performance. The second hypothesis is as follows,

H2: There is positive relationship between work-life and organizational commitment. 


\subsection{Empowerment practices}

The first definition of empowerment practices goes back to 1788, where it was considered as an ability for giving a responsibility to a person who is qualified to act for a position (Naderi et al., 2007). For over fifty years, empowerment practices have been a subject of intensive investigation (Nykodym et al., 1994). Samat et al. (2006) explained that empowering employee could increase the quality of product and services. According to Jahangiri (2007), employees with better skills could better contribute to their organizations. Empowering practices include employee commitment and the level of their contribution (McEwan \& Sackett, 1997; Val, 2003; Greasley et al., 2008). Spreitzer (1995) performed a study and found a positive relationship between empowering activities and job satisfaction. Meyerson et al. (2008) reported that when employee is empowered, he/she will feel more confident and could be expected well when a job is assigned to a person who has already been under exclusive training. Moye and Henkin (2006) reported that these people could even make better decisions and could attract more customers. Lee et al. (2006) indicated that empowering people could lead an organization to have more commitment people. Bhatnagar (2007) and Denton (1994) also provided some evidence to support Lee's report. The third hypothesis of this study is as follows,

$\mathrm{H} 3$ : There is positive relationship between empowering practices and organizational commitment.

\subsection{Organizational commitment}

For over 30 years, the concept of organizational commitment has been improved (Putterill \& Rohrer, 1995). Organizational commitment is a concept has multi dimensional concept, which yields positive outcome on job including a remarkable reduction on work absence, citizenship organizational behavior, etc. (Chew, 2008). There are two approaches on organizational commitment: The first one specifies that commitment is a primary objective for continuous contribution to work and the second one is associated with the level of interest among members of organization, which is also a reflection from employees to organization (Jaramillo \& Nixson, 2005).

According to Alvani (1998), people who have strong commitment to organization spend more time on their work and perform their jobs with more discipline. McCabe (2008) explained that commitment is the most influential factors for the success of an organization. Freund (2003) believes that a highly committed person increase organizations' efficiency more effectively. Aube et al. (2007) also support this idea and suggest increasing organizational commitment through hiring people with strong motivations for long-term positions. There are many reasons to support this argument. First, there are many evidences, which indicate that organizational commitment has positive relationship with job satisfaction, job performance and employee's leave. Second, organizational commitment is relatively a new concept, which is different from job satisfaction (Hosseini et al., 2008). Finally, commitment represents citizenship behavior because it influences this factor, substantially.

H4: There is positive relationship between organizational commitment and OCB.

\subsection{Organizational citizenship behavior}

Organizational atmosphere is influenced significantly by organizational citizenship behavior (OCB) because it makes significant change on people's perspective on working conditions (Dimitriades, 2007; Van Dyne, 1990; Van Dyne et al., 1994). In other words, organizational effectiveness and customer's feedback from the quality of services have direct relationship with OCB (Torlak, 2007). Bolino et al. (2003) explained that OCB we cannot improve it directly. According to Bell (2002) OCB includes five perspectives including friendship, responsibility, kindness, courtesy and sportsmanship. McKenzie et al. (1993) explained that a kind organization contributes more on society. Podsakoff et al. (1990) believed that those employees with strong sense of sportsmanship could substantially attract more customers for their organizations. 


\section{Proposed study}

The proposed study of this paper investigates whether training and development opportunities, work life policy and empowering practices could increase organizational commitment, which eventually yields an improvement on OCB. Fig. 1 shows details of our survey.

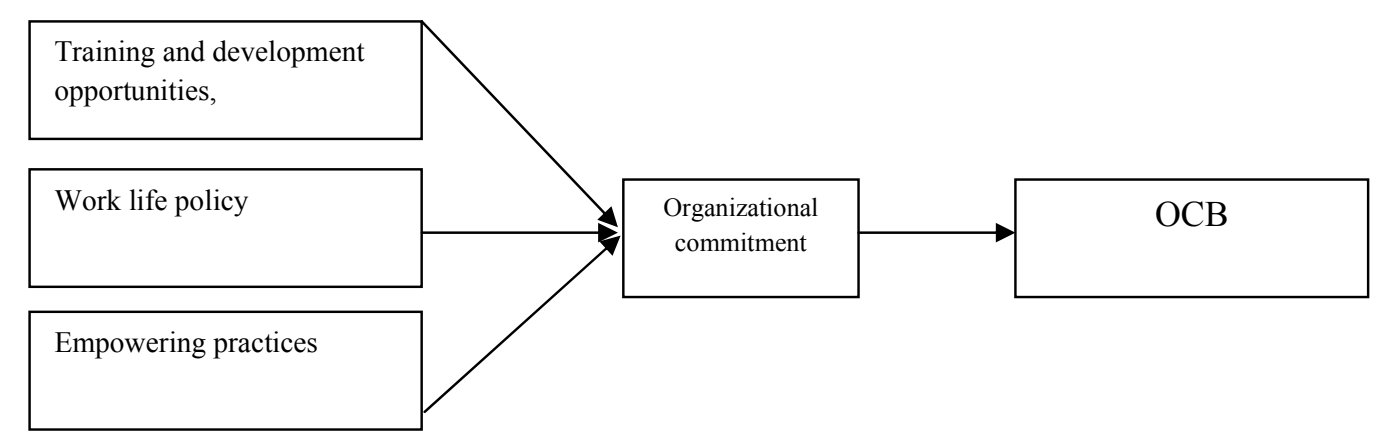

Fig. 1. The proposed study

The proposed study of this paper has three independent variables including training and development opportunities, work-life policy and empowering practices. There is one intermediate variable, which is organizational commitment and OCB is the only dependent variable. The study uses Likert based questionnaire from completely disagree, 1 to completely agree, 5 . There are 35 questions associated with five variables summarized in Table 1 .

\section{Table 1}

Questions and main variables of the proposed study

\begin{tabular}{lc}
\hline Title & \# of questions \\
\hline Training and development opportunities & 6 \\
Work life policy & 4 \\
Empowering practices & 7 \\
organizational commitment & 8 \\
Organizational Citizenship Behavior & 10 \\
\hline
\end{tabular}

In this survey, we have used the following equation to calculate the sample size,

$5 q \leq n \leq 15 q$,

where $n$ and $q$ are sample size and number of questions in the questionnaire, respectively. Since there are 35 questions in our survey, the minimum sample size must be between 175 and 525 . We have distributed 220 questionnaires and collected 199. Cronbach Alpha (Cronbach, 1951) was calculated as 0.94 , which well above the minimum acceptable limit, 0.70 , and we can conclude the results are highly valid. We have used structural equations to study the relationship among different component with factor analysis. The analysis was performed using LISREL software package and they are discussed. Let CDT represents training and development opportunities, WL represents work-life policy and EMP represents empowering practices, respectively. Let COM represents organizational commitment and ORB represents organizational citizenship behavior, respectively. Let $\gamma_{i j}$ be structural coefficients of external variables to internal variables and $\beta_{i j}$ be structural coefficients of internal variables, respectively. Therefore, we have the following relationships,

$C O M=\gamma_{11} C D T+\gamma_{12} W L+\gamma_{13} E M P+\xi_{1}$ 
$O R B=\beta_{11} C O M+\xi_{2}$

\section{Results}

The first step in our survey is to examine the values of t-students and Fig. 2 shows details of our survey.

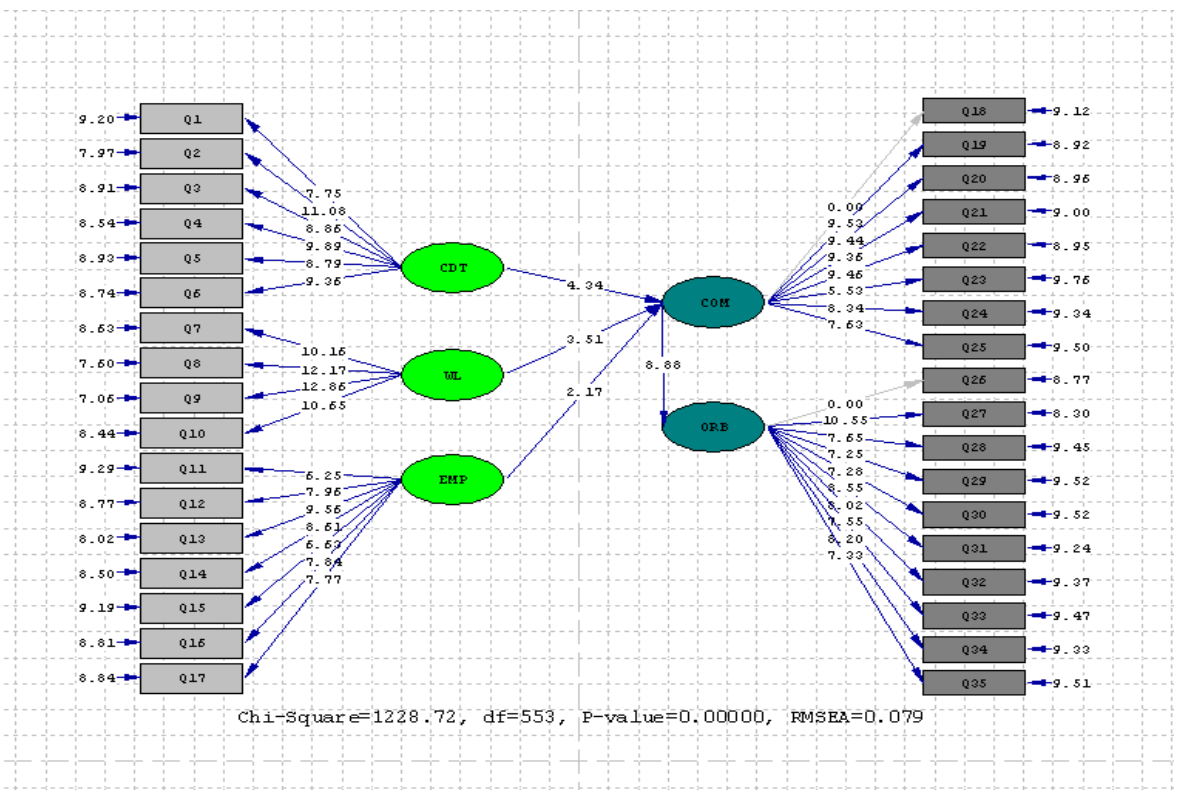

Fig. 2. T-student results among different variables

As we can observe from the results of Fig. 2, most t-students are highly valid, which indicates they represents the results are meaningful.

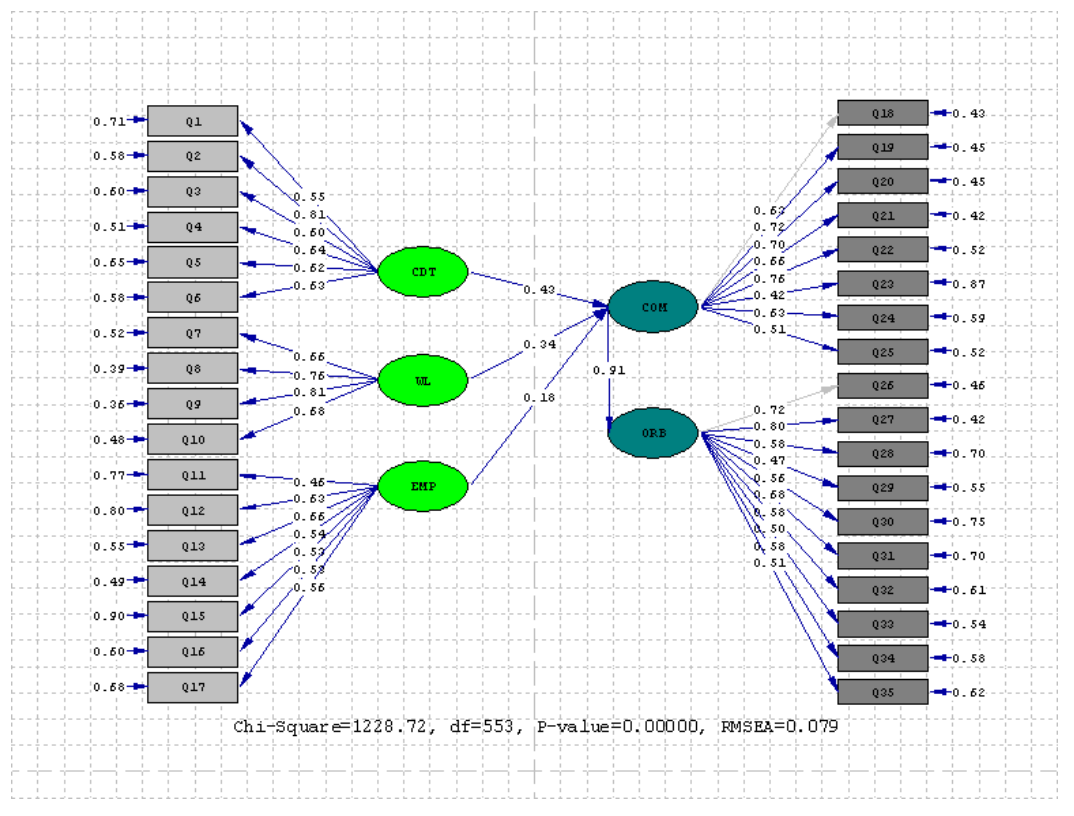

Fig. 3. The results of estimated coefficients

Based on the results represented in Fig. 3, we have extracted two relationships as follows, 


$$
\begin{gathered}
C O M=0.43 C D T+0.43 W L+0.18 E M P, \\
O R B=0.91 C O M .
\end{gathered}
$$

Table 2 shows correlation values among different variables. As we can observe from the results of the table, there is a strong correlation between ORB and COM and between CDT and COM and between WL and COM with $0.91,0.78$ and 0.76 , respectively.

Table 2

Correlation values among different variables

\begin{tabular}{llllll}
\hline & COM & ORB & CDT & WL & EPM \\
\hline COM & 1.00 & & & & \\
ORB & 0.91 & 1.00 & & & \\
CDT & 0.78 & 0.71 & 1.00 & & \\
WL & 0.76 & 0.69 & 0.71 & 1.00 & \\
EPM & 0.65 & 0.59 & 0.59 & 0.61 & 1.00 \\
\hline
\end{tabular}

Table 3 shows details of our four hypotheses.

\section{Table 3}

The results of four hypotheses

\begin{tabular}{lcccc}
\hline Hypothesis & Parameter & Coefficient & T & Result \\
\hline H1: Training and development opportunities have positive \\
$\begin{array}{l}\text { relationship with organizational commitment. } \\
\text { H2: There is positive relationship between work-life and } \\
\text { organizational commitment. }\end{array}$ & $\gamma_{11}$ & 0.43 & $4.34>1.96$ & Confirm \\
$\begin{array}{l}\text { H3: There is positive relationship between empowering } \\
\text { practices and organizational commitment. }\end{array}$ & $\gamma_{13}$ & 0.34 & $3.51>1.96$ & Confirm \\
$\begin{array}{l}\text { H4: There is positive relationship between organizational } \\
\text { commitment and OCB. }\end{array}$ & $\beta_{11}$ & 0.18 & $2.17>1.96$ & Confirm \\
\hline
\end{tabular}

The root mean square error of approximation (RMSEA) is calculated as 0.079 , which is relatively a good value for our results. In addition, the goodness of fit index (GFI) and adjusted GFI (AGFI) are 0.74 and 0.70 , respectively.

This means that our estimations are suitable. We have also considered Normed fit index (NFI), NonNormed fit index (NNFI), comparative fit index (CFI) and incremental fit index (IFI) as 0.9, 0.94, 0.94 and 0.94 , respectively. These observations clearly validate our results since they are well above 0.9 .

\subsection{First hypothesis: Training opportunities and organizational commitment}

$\left\{\begin{array}{l}H_{0} \text { : Training and development opportunities do not have positive relationship with organizational commitment. } \\ H_{1} \text { : Training and development opportunities have positive relationship with organizational commitment. }\end{array}\right.$

The regression function yields the following results,

$C O M=0.43 C D T+0.34 W L+0.18 E M P$

Evaluation of this hypothesis using the empirical evidences and the t-test (4.34) indicates that given the significance level of sig: 0.000 , which is less than $\alpha=0.05$. Therefore, the hypothesis that states there is no relationship between training and development opportunities and organizational 
commitment will be rejected and the hypothesis based on the relationship between two variables will be confirmed with a value of 0.43 .

\subsection{Second hypothesis: Work-life and organizational commitment}

$\left\{\begin{array}{l}H_{0}: \text { Work-life commitment do not have positive relationship with organizational commitment. } \\ H_{1} \text { : Work-life commitment have positive relationship with organizational commitment. }\end{array}\right.$

Again, our test on this hypothesis using the empirical evidences and the t-test (3.51) indicates that given the significance level of sig: 0.000 , which is less than $\alpha=0.05$. Therefore, the hypothesis that states there is no relationship between work-life policy and organizational commitment will be rejected and the hypothesis based on the relationship between two variables will be confirmed with a value of 0.34 .

\subsection{Third hypothesis: Empowering practices and organizational commitment}

$\left\{\begin{array}{l}H_{0} \text { : Empowering practices do not have positive relationship with organizational commitment. } \\ H_{1} \text { : Empowering practices have positive relationship with organizational commitment. }\end{array}\right.$

Again, our test on this hypothesis using the empirical evidences and the t-test (2.17) indicates that given the significance level of sig: 0.000 , which is less than $\alpha=0.05$. Therefore, the hypothesis that states there is no relationship between empowering practices and organizational commitment will be rejected and the hypothesis based on the relationship between two variables will be confirmed with a value of 0.18 .

\subsection{Fourth hypothesis: Organizational commitment and OCB}

$\left\{\begin{array}{l}H_{0}: \text { There is no positive relationship between organizational commitment and OCB. } \\ H_{1} \text { : There is a positive relationship between organizational commitment and OCB. }\end{array}\right.$

Again, our test on this hypothesis using the empirical evidences and the t-test (2.17) indicates that given the significance level of sig: 0.000 , which is less than $\alpha=0.05$. Therefore, the hypothesis that states there is no relationship between organizational commitment and OCB will be rejected and the hypothesis based on the relationship between two variables will be confirmed with a value of 0.91 .

In summary, we have confirmed that we can improve organizational commitment through investing on training and educational programs, which is what the other people reported in previous studies (Antonacopoulou, 2000). Based on the results of the second hypothesis, we can conclude that when there is a good balance between work and life, there will be better outcome on organizational commitment, which yields better work performance (Deery, 2008). The third hypothesis has confirmed that there was a positive relationship between empowering workforce and organizational commitment, which confirms older studies (Lee et al., 2006). Finally, we can claim that the three mentioned factors could substantially increase organizational commitment, which also influences positively on OCB (Foote, 2005).

\section{Conclusion}

We have presented an empirical study to measure the relevant impact of different factors such as educational opportunities, work-life policy, empowerment activities on organizational commitment directly and the organizational citizenship behavior indirectly. The proposed study of this paper investigated the relative importance of Organizational Citizenship Behavior (OCB) in different universities located in the province of Ilam, Iran. The study distributed 220 questionnaires and 
collected 199 and they were analyzed using LISREL software package. There were four hypotheses associated with this survey and the results indicated that educational opportunities, work-life policy, empowerment activities had strong positive relationship on organizational commitment and organizational commitment could influence organizational citizenship behavior, accordingly.

\section{Acknowledgment}

The author would like to thank the anonymous referees for their constructive comments on earlier version of this work.

\section{References}

Alvani, M., \& Memarzadeh, G.H.(1998). Organizational behavior. Tehran . publication Morvarid(translated in Persian).

Antonacopoulou, E.P. (2000). Reconnecting education, development training through learning: A holographic perspective. Education + Training, 42 (4/5), 255-263.

Aube, C., Rousseau.V., \& Morin, E.M. (2007). Perceived organizational support and organizational commitment The moderating effect of locus of control and work autonomy. Journal of Managerial Psychology, 22 (5), 479-495.

Bell, S.J., \& Menguc, B. (2002), The employee-organization relationship, organizational citizenship behaviours , and superior service quality. Journal of Retailing, 78(2), 131-146.

Bhatnagar, J. (2007). Predictors of organizational commitment in India: strategic HR roles, organizational learning capability and psychological empowerment. The International Journal of Human Resource Management, 18 (10),1782-1812.

Bienstock, C., Demoranville, W. C., \& Smith, K. R. (2003). organizational citizenship behavior and service quality. Journal of Services Marketing, 17(4), 357-378.

Bolino, M.C., \& Turnley, W.H. (2003). Going the Extra Mile: Cultivating and Managing Employee Citizenship Behavior. Academy of Management Executive, 17, 60-71.

Brown, M., Boyle, B., \& Boyle, T.(2002). Professional development and management training needs for heads of departments in UK secondary schools. Journal of Educational Administration,40(1), $31-43$.

Chang, E. (1999). Career commitment as a complex moderator of organizational commitment and turnover intention. Human Relations, 52(10), 1257-1278.

Chew, J., \& Chan, C.C.A. (2008). Human resource practices, organizational commitment and intention to stay. International Journal of Manpower,29( 6),503-522.

Chughtai, A.A. \& Zafar, S. (2006). Antecedents and Consequences of Organizational Commitment among Pakistani university teachers. Applied H.R.M. Research, 11(1), 39-64.

Cronbach, L. J. (1951). Coefficient alpha and the internal structure of tests. Psychometrika, 16(3), 297-334.

Deery, M. (2008). Talent management, work-life balance and retention strategies. International Journal of Contemporary Hospitality Management, 20 (7), 792-806.

Denton, D.K. (1994). Empowerment through employee involvement and participation Ford's development and training programs. Empowerment in Organizations, 2(2), $22-28$.

Dimitriades, Z.S. (2007). The influence of service climate and job involvement on customer-oriented organizational citizenship behavior in Greek service organizations: a survey. Employee Relations, 29 (5), 469-491.

Dockel, A., Basson, J.S., \& Coetzee, M.(2006).The effect of retention factors on organizational commitment:An investigation of high technology employees. Journal of Human Resource Management, 4 (2), 20-28.

Freund, A., \& Carmeli, A. (2003). An empirical assessment: reconstructed model for five universal forms of work commitment. Journal of Managerial Psychology,18(7), 708-725.

Foote, D.A., Seipel, S.J., Johnson, N.B., \& Duffy, M.K. (2005). Employee commitment and organizational policies. Management Decision, 43(2), 203-219. 
Garavan, T.N. (1997). Training, development, education and learning: different or the same?. Journal of European Industrial Training, 21(2), 39-50.

Garavan, T.N., Barnicle, B., \& Heraty, N. (1993). The training and development function: Its search for power and influence in organizations. Journal of European Industrial Training, 17 (7), 22-32.

Gautam,T, Dick, R.V., Wagner, U., Upadhyay, N., \& Davis, A.J. (2004). Organizational citizenship behavior and organizational commitment in Nepal. sciencelinks.jp/j-east/article/.

Glass, J.L., \& Riley, L. (1998). Family responsive policies and employee retention following childbirth. Social Forces, 76(4), 1401-1435.

Greasley, K., Bryman, A., Dainty, A., Price, A., Naismith, N., \& Soetanto, R. (2008). Understanding empowerment from an employee perspective What does it mean and do they want it?. Team Performance Management, 14 (1/2), 39-55.

Hosseini, M., Mehdizadeh Ashrafi, A.(2010). Identification of effective factors on organizational commitment . Management Journal. No 18.

Jaramillo, F., \& Nixson, R.(2005).The effect of law enforcement stress on organizational commitment. An International Journal of Police Strategic and Management, 28, 321-336.

Jarrar, Y.F., \& Zairi, M. (2002). Employee empowerment-a UK survey of trends and best practices. Managerial Auditing Journal, 17(5), 266-271.

Joolideh, F. \& Yeshodhara, K. ( 2009). Organizational commitment among high school teachers of India and Iran .Journal of Educational Administration, 47 (1), 127-136.

Kahn, R.L., Wolfe, D.M., Quinn, R.P., Snoek, J.D., \& Rosenthal, R.A. (1964). Organizational stress: Studies in role conflict and ambiguity. New York: John Wiley \& Sons Inc.

Kalleberg, A.L., \& Moody, J.W.(1994). Human resource management and organizational performance. American Behavioral Scientist,37, 948.

Katz, D., \& Kahn, R.L. (1978). The Social Psychology of Organization. New York: John Wiley \& Sons Inc.

Khayyat, R.A. (1998). Training and development needs assessment: a practical model for partner institutes. Journal of European Industrial Training, 22(1), 18-27.

Koster, F. \& Sanders, K.(2006). Organisational citizens or reciprocal relationships?An empirical comparison. Personal Review, 35 (5), 519-537.

Lee, Y.K., Nam, F.H., Park, D.H., \& Lee, K.A. (2006). What factors influence customer-oriented prosocial behavior of customer-contact employees?. Journal of Services Marketing, 20(4), 251264.

Liu, A.M.M., Chiu, W.M., \& Fellows, R. (2007). Enhancing commitment through work empowerment. Engineering Construction and Architectural Management,14(6), 568-580.

Liu, C.M. (2007). The early employment influences of sales representatives on the development of organizational commitment. Employee Relations, 29(1), 5-15.

Liu, Y. (2009). Perceived organizational support and expatriate organizational citizenship behavior: The mediating role of affective commitment towards the parent company. Personnel Review, 38 (3), 307-319.

MacKenzie, S.B., Podsakoff, P.M., \& Fetter, R. (1993). The impact of organizational citizenship behaviour on evaluations of salesperson performance. Journal of Marketing, 7(1), 70-78.

McCabe, T.J., \& Garavan, T.N. (2008). A study of the drivers of commitment amongst nurses The salience of training, development and career issues. Journal of European Industrial Training, 32 (7), 528-568.

McEwan, A.M., \& Sackett, P. (1997). Theoretical considerations of employee empowerment within computer integrated manufacturing production. Empowerment in Organizations, 5 (3), 129-138.

Meyer, J.P. \& Allen N.J. (1984). Testing the "Side Bet Theory" of organizational commitment: Some methodological considerations. Journal of Applied Psychology, 67:372-278.

Meyerson, S.L., \& Kline.T.J.B. (2008). Psychological and environmental empowerment: antecedents and consequences. Leadership \& Organization Development Journal ,29 (5), 444-460. 
Moye, M.J., \& Henkin, A.B. (2006). Exploring associations between employee empowerment and interpersonal trust in managers. Journal of Management Development, 25(2), 101-117.

Naderi,N., Rajaeepoor,S., \& Jamshidian, A. (2007) . Concepts and strategies of empowering employees . Tadbir journal, 186.

Noor, A. (2009). Examining organizational citizenship behavior as the outcome of organizational commitment: a study of universities teachers of Pakistan. Army public college of management sciences(APCOMS).

Organ, D. W., \& Ryan K. (1995) A meta-analytic review of attitudinal and dispositional predictors of organizational citizenship behavior. Personnel Psychology, 48, 775-802.

Pleck, J. H., Staines, G., \& Lang, L. (1980). Conflicts between work and family life. Monthly Labors Review, 29-32.

Podsakoff, P.M., MacKenzie, S.B., Moorman, R.H., \& Fetter, R. (1990). Transformational leader behaviours and their effects on followers' trust in leader, satisfaction, and organizational citizenship behaviours. Leadership Quarterly, 1(2), 107-142.

Podsakoff, P. M., Mackenzie, S. B., Paine, B. P., \& Bachrach, D. G. (2000). Organizational citizenship behavior: A critical review of the theoretical and empirical literature and suggestions for future research. Journal of Management, 26, 513-563.

Porter, L. W., Steers, R. M., Mowday, R. T., \& Boulian, P. V. (1974). Organizational commitment, job satisfaction, and turnover among psychiatric technicians. Journal of Applied Psychology, 59, 603-609.

Putterill, M.S., \& Rohrer, T.C. (1995). A causal model of employee commitment in a manufacturing setting. International Journal of Manpower, 16(5/6), 56-69.

Robbins, S. (1993).Organizational behavior. $6^{\text {th }}$ ed. Prentice-Hall.

Samat, N., Ramayah, T., \& Saad, N.M. (2006). TQM practices, service quality, and market orientation some empirical evidence from a developing country. Management Research News, 29(11), 713-728.

Schwartz, D.B. (1996). The impact of work-family policies on women's career development: boon or bust?. Women in Management Review, 11(1), 5-19.

Simon, M., Kummerling, A., \& Hasselhorn, H.M. ( 2004). Work-home conflict in the European nursing profession. International Journal Occupational Environmental Health, 10(4), 384-391.

Spreitzer, G.M. (1995). Psychological empowerment in the workplace: Dimensions, measurement, and validation. The Academy of Management Journal, 38(5), 1442-1465.

Šušnjar, Š. G., \& Zimanji, V. (2006). Menadžment ljudskih resursa, Ekonomski fakultet, Subotica.

Torlak, O., \& Koc, U.(2007). Materialistic attitude as an antecedent of organizational citizenship behavior. Management Research News, 30(8), 581-596.

Val, M.P.D., \& Lloyd, B. (2003). Measuring Empowerment. Leadership and Organization Development Journal, 24(2),102-108

Van Dyne, L., \& Cummings, L.L. (1990). Extra-role Behaviours: in pursuit of construct and definitional clarity”, paper presented at the Annual Meeting of the Academy of Management. San Francisco, CA.

Van Dyne, L., Graham, J.W., \& Dienesch, R.M. (1994). Organizational citizenship behaviour: construct redefinition, measurement, and validation. Academy of Management Journal, 37(4), $765-$ 802 . 